Andrews University

Digital Commons @ Andrews University

Faculty Publications

$3-1-2010$

\title{
Foraging-Related Activity of Bald Eagles at a Washington Seabird Colony and Seal Rookery
}

James L. Hayward

Andrews University, hayward@andrews.edu

Joseph G. Galusha

Walla Walla University

Shandelle M. Henson

Andrews University, henson@andrews.edu

Follow this and additional works at: https://digitalcommons.andrews.edu/pubs

Part of the Ornithology Commons

\section{Recommended Citation}

Hayward, James L.; Galusha, Joseph G.; and Henson, Shandelle M., "Foraging-Related Activity of Bald Eagles at a Washington Seabird Colony and Seal Rookery" (2010). Faculty Publications. 1875.

https://digitalcommons.andrews.edu/pubs/1875

This Article is brought to you for free and open access by Digital Commons @ Andrews University. It has been accepted for inclusion in Faculty Publications by an authorized administrator of Digital Commons @ Andrews University. For more information, please contact repository@andrews.edu. 


\section{Foraging-Related Activity of Bald Eagles at a Washington Seabird Colony and Seal Rookery}

Authors: Hayward, James L., Galusha, Joseph G., and Henson, Shandelle M.

Source: Journal of Raptor Research, 44(1) : 19-29

Published By: Raptor Research Foundation

URL: https://doi.org/10.3356/JRR-08-107.1

BioOne Complete (complete.BioOne.org) is a full-text database of 200 subscribed and open-access titles in the biological, ecological, and environmental sciences published by nonprofit societies, associations, museums, institutions, and presses.

Your use of this PDF, the BioOne Complete website, and all posted and associated content indicates your acceptance of BioOne's Terms of Use, available at www.bioone.org/terms-of-use.

Usage of BioOne Complete content is strictly limited to personal, educational, and non - commercial use. Commercial inquiries or rights and permissions requests should be directed to the individual publisher as copyright holder.

BioOne sees sustainable scholarly publishing as an inherently collaborative enterprise connecting authors, nonprofit publishers, academic institutions, research libraries, and research funders in the common goal of maximizing access to critical research. 


\title{
FORAGING-RELATED ACTIVITY OF BALD EAGLES AT A WASHINGTON SEABIRD COLONY AND SEAL ROOKERY
}

\author{
JAMES L. HAYWARD ${ }^{1}$ \\ Department of Biology, Andrews University, Berrien Springs, MI 49104 U.S.A.
}

JOSEPH G. GALUSHA

Department of Biological Sciences, Walla Walla University, College Place, WA 99324 U.S.A.

\author{
SHANDElle M. Henson \\ Department of Mathematics, Andrews University, Berrien Springs, MI 49104 U.S.A.
}

\begin{abstract}
From 1980 to 1998, Washington's Bald Eagle (Haliaeetus leucocephalus) population increased at an annual rate of $10 \%$. Over the same time period, foraging activity of Bald Eagles at marine bird breeding colonies also increased. From 1993 to 2008, we observed foraging-related behavior of Bald Eagles on Violet Point, Protection Island. This island hosts more than $70 \%$ of the breeding seabirds in Washington's inner seaways and serves as an important rookery for harbor seals (Phoca vitulina). We found that (1) eagles landed more frequently in seal haul-out (beach) areas than in gull-nesting (non-beach) areas of Violet Point, and that subadult eagles were more likely to land in gull-nesting areas than were adult eagles; (2) the presence of eagles on the beach was positively related to the presence of harbor seals on the beach; (3) a greater-than-expected number of adult eagles as compared with subadult eagles preyed on gull chicks; (4) subadult and adult eagles that attempted prey capture were equally successful at snatching gull chicks from the gull colony; (5) eagles were more likely to prey on gull eggs in tall grass than on gull eggs in sparse vegetation. Prey remains beneath one eagle nest on the island did not accurately reflect the range and relative frequencies of observed eagle predation events. Although seal afterbirths and dead pups constitute a major component of the diet of Bald Eagles on the island, the effect of eagles on live seals is probably negligible. In contrast, direct predation and indirect effects of eagle activity on Glaucous-winged Gull (Larus glaucescens) reproductive success may be substantial and may have been partly responsible for a $44 \%$ decrease in the number of gull nests in the colony from 1993-2008.
\end{abstract}

KeY Words: Bald Eagle, Haliaeetus leucocephalus; Glaucous-winged Gull; Larus glaucescens; diet; foraging; harbor seals; Protection Island; Washington. ACTIVIDADES DE FORRAJEO DE HALIAEETUS LEUCOCEPHALUS EN UNA COLONIA DE AVES MARI-
NAS Y EN UN SITIO DE AGRUPACIÓN DE FOCAS EN WASHINGTON

Resumen.-Desde 1980 a 1998, la población de Haliaeetus leucocephalus aumentó a una tasa anual del 10\%. Durante el mismo período de tiempo, la actividad de forrajeo de $H$. leucocephalus en las colonias reproductivas de aves marinas también incrementó. Desde 1993 a 2008, observamos los comportamientos vinculados al forrajeo de las águilas en Violet Point, isla Protection. Esta isla alberga más del 70\% de las aves marinas que anidan en las costas internas de los canales marinos de Washington y sirve como un importante sitio de agrupación de la foca Phoca vitulina. Encontramos que (1) las águilas aterrizaron más frecuentemente en las áreas sin focas (playas) que en las áreas donde anidan las gaviotas (no de playa) de Violet Point, y que las águilas subadultas aterrizaron con una mayor probabilidad en las áreas de anidación de las gaviotas que las águilas adultas; (2) la presencia de las águilas en la playa estuvo relacionada positivamente con la presencia de las focas en la playa; (3) un número mayor del esperado de águilas adultas en comparación con las águilas subadultas depredaron sobre los pichones de las gaviotas; (4) las águilas subadultas y adultas que intentaron capturar presas fueron igualmente exitosas en arrebatar pichones de gaviota de la colonia de gaviotas; (5) las águilas tuvieron una mayor probabilidad de depredar los huevos de las gaviotas en sitios de pastos altos que en sitios de vegetación rala. Los restos de presas

${ }^{1}$ Email address: hayward@andrews.edu 
encontrados debajo de un nido de águila en la isla no reflejaron de modo preciso el rango y las frecuencias relativas de los eventos de depredación observados para las águilas. Aunque las placentas de las focas y los cachorros muertos constituyen un componente importante de la dieta de $H$. leucocephalus en la isla, el efecto de las águilas sobre las focas vivas es probablemente insignificante. En contraste, la depredación directa y los efectos indirectos de la actividad de las águilas sobre el éxito reproductivo de Larus glaucescens puede ser sustancial y puede haber sido en parte responsable del descenso del $44 \%$ en el número de nidos de gaviotas en la colonia desde 1993 a 2008.

[Traducción del equipo editorial]

Bald Eagles (Haliaeetus leucocephalus) play major roles in the dynamics of coastal marine food webs where they feed opportunistically on a wide variety of fish, birds, and mammals (Anthony et al. 2008, Stalmaster 1987). In some areas, eagles limit the reproductive success of some prey populations such as Common Murres (Uria aalge; Parrish et al. 2001), Glaucous-winged Gulls, (Larus glaucescens; Sullivan et al. 2002), and Great Blue Herons (Ardea herodias; Vennesland and Butler 2004), and affect the activity budgets of Glaucous-winged Gulls (White et al. 2006). Bald Eagle populations have risen dramatically in recent decades, a trend attributed primarily to reduced environmental levels of DDT and increased protection from human disturbance (Stalmaster 1987).

The state of Washington contains one of North America's largest breeding populations of Bald Eagles, which, from 1980 to 1998, increased at an annual rate of $10 \%$; much of this increase occurred west of the Cascade Crest, where during this interval the number of nesting territories rose $355 \%$, from 157 to 715 (Watson et al. 2002). The Salish Sea, a saltwater system extending from the Pacific Ocean into the western parts of Washington and British Columbia, provides ideal nesting and feeding habitats for these birds.

Protection Island, located at the east end of the Strait of Juan de Fuca, occupies a central location in the Salish Sea and hosts more than $70 \%$ of the breeding seabirds in Washington's inland waters (Speich and Wahl 1989); it also serves as an important rookery for harbor seals (Phoca vitulina; Kroll 1993, Hayward et al. 2005). We have studied the behavioral ecology of marine birds and mammals breeding on this island since 1979 (e.g., Galusha et al. 1987, Hayward et al. 2005, Henson et al. 2007). Beginning in the early 1990s we noted a dramatic increase in eagle activity on the island (Galusha and Hayward 2002), particularly on Violet Point where most of the gulls nest and where seal haul-out and pupping occurs.

Previous studies of Bald Eagle interactions with Pacific Northwest marine bird colonies have evalu- ated direct and indirect effects of increased Bald Eagle activity on the reproductive success of prey species such as Common Murres (Parrish 1995, Parrish et al. 2001) and Glaucous-winged Gulls (Sullivan et al. 2002, White et al. 2006). Except for a brief report (Galusha and Hayward 2002) and general comments on predation in papers focused on other topics, however, eagle behavior on these colonies has been poorly documented. Moreover, little has been published about behavioral interactions between Bald Eagles and harbor seals, which commonly occupy the same marine communities.

Here we describe foraging-related Bald Eagle behavior on Violet Point, Protection Island. We also test five null hypotheses regarding the foraging activities of eagles in relation to nesting Glaucouswinged Gulls and hauled-out harbor seals: (1) subadult and adult eagles land with equal frequency in seal haul-out (beach) and in gull-nesting (nonbeach) parts of Violet Point; (2) the presence of eagles on the beach is unrelated to the presence of harbor seals on the beach; (3) the relative numbers of subadult and adult eagles participating in a feeding event are independent of the type of food item involved; (4) subadult and adult eagles attempting prey capture are equally successful at snatching gull chicks from the colony; and (5) eagles prey on gull eggs in tall grass and sparse vegetation habitats with equal frequency.

\section{Study AREA}

Protection Island (PI), Jefferson County, Washington $\left(48^{\circ} 08^{\prime} \mathrm{N}, 122^{\circ} 55^{\prime} \mathrm{W}\right)$, is located in the southeastern corner of the Strait of Juan de Fuca, close to the mouth of Admiralty Inlet and $2.3 \mathrm{~km}$ north of the Olympic Peninsula and mouth of Discovery Bay. The island is about $3 \mathrm{~km}$ long and $1 \mathrm{~km}$ wide. Two gravel spits, Violet Point and Kanem Point, extend from the southeastern and southwestern ends, respectively, of the upper island plateau (Fig. 1). The plateau, 35-76 $\mathrm{m}$ asl and separated from the spits by steep bluffs, is primarily grassland habitat with two small wooded areas (Cowles and Hayward 


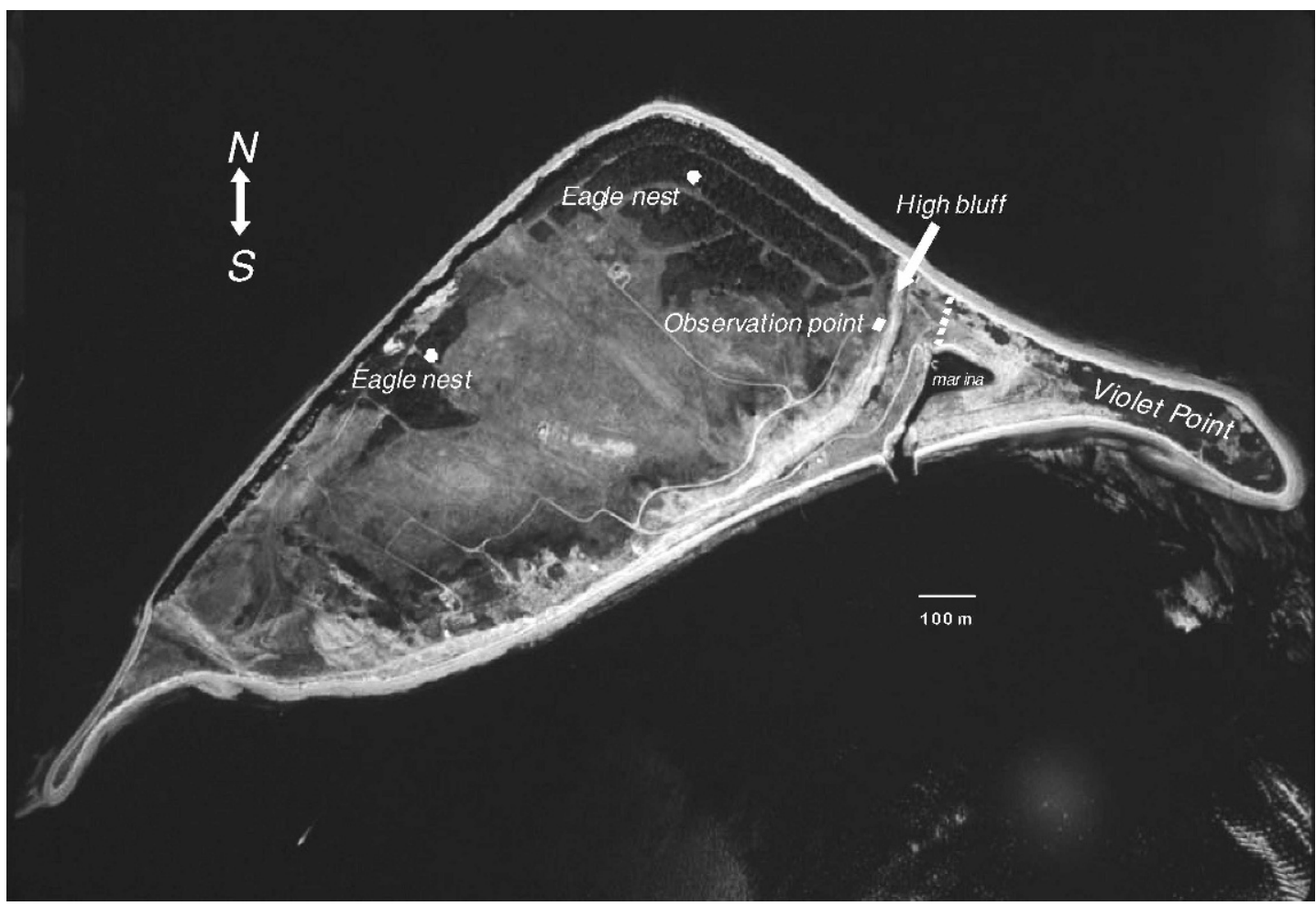

Figure 1. Aerial view of Protection Island at noon on 31 July 1999, showing locations of Violet Point, the marina, the eagle nests, and the observation point at the top of the steep bluff. The Glaucous-winged Gull colony occupied most of Violet Point, except for the beach and a band approximately $100 \mathrm{~m}$ wide at the base of the high bluff, delineated by the dashed line and marina shore. Harbor seal haul-out occurred exclusively on the beach. Photo by Washington Department of Transportation.

2008). The island is managed as Protection Island National Wildlife Refuge by the U.S. Fish and Wildlife Service and is closed to the public.

One Bald Eagle nest consistently has been located in the northeastern wooded area during this study. The nest is located $20 \mathrm{~m}$ high in a Douglas fir (Pseudotsuga menziesii). One or two eaglets have been raised successfully on Protection Island most years since the early 1980s (Washington Department of Fish and Wildlife unpubl. data). In 2008, we noted a second active and successful nest approximately $0.5 \mathrm{~km}$ southwest of the older nest and located at the eastern edge of the second wooded area (Fig. 1). In addition to the breeding pairs, many nonresident eagles use Protection Island for foraging and resting.

In 1993, at the beginning of this study, we counted 5135 Glaucous-winged Gull nests on Violet Point; this number declined to 2852 nests by 2008 (unpubl. data). Gull nests were distributed within sparsely vegetated areas ("sparse vegetation"), and alongside or tunneled into dense patches of tall (0.5-1.5 m) beach grass (Leymus mollis; "tall grass") . The gull colony extends from the eastern end of the spit to about $100 \mathrm{~m}$ from the base of the bluff at the western end (Fig. 1). Hundreds of other nests are located on the upper part of the island along its southern margin and in a southwestern dune area.

Protection Island also contains the largest Rhinoceros Auklet (Cerorhinca monocerata) colony in the contiguous United States, where an estimated 35715 breeding pairs burrow along the steep bluffs (Pearson et al. 2009). Other seabirds that breed on the island include Pigeon Guillemots (Cepphus columba), Double-crested Cormorants (Phalacrocorax auritus), Pelagic Cormorants ( $P$. pelagicus), Tufted Puffins (Fratercula cirrhata), and Black Oystercatchers (Haematopus bachmani). Several hundred harbor seals (Kroll 1993, Hayward et al. 2005) and up to six northern elephant seals (Mirounga angustirostris; Hayward 2003) haul out along the beaches. 


\section{Methods}

From 1993 to 2002, $1696 \mathrm{hr}$ during 163 d were spent observing eagle behavior on and over Violet Point from the top of the high bluff at its western end (Fig. 1). Observations were made with $10 \times$ binoculars and (from 1995 on) a 20-60× zoom spotting scope. During continuous observations, from $0500 \mathrm{H}$ to $2100 \mathrm{H}$ (Pacific Standard Time here and below) on each Thursday, 1 July-5 August 1993, 30 June-4 August 1994, and 29 June-3 August 1995 (six sample days each year), we recorded the time of appearance, age class (subadult, adult, or unknown), and eventual landing site (if known) for each flying eagle we observed. At the top of each hour, counts also were made of the number of harbor seals hauled out on the beach. From $0500 \mathrm{H}$ to $2000 \mathrm{H}$ each Wednesday or (in 1995) Thursday, 29 June-3 August 1995, 2 July-13 August 1997, 1 July12 August 1998, 30 June-18 August 1999, and 23 May-20 June 2001 (total sample $=33 \mathrm{~d}$ ), except during fog, hourly counts were made of subadult and adult (defined in this study as any white-headed eagle) Bald Eagles and harbor seals observed on Violet Point. During 1996, 2000, and 2002 systematic counts were not made, but extensive observations of Violet Point occurred on most days from late June to late July/early August in conjunction with other studies. On these days we always recorded any noticeably large numbers of eagles seen at one time during the day. Maximum counts during these four years were considered "nonsystematic" and identified as such in the Results.

During the hourly counts of eagles on Violet Point during weekly sample days in 1998 and 1999, counts also were made of numbers of seal pups that could be seen on the beach. The number of new pups each week was estimated by subtracting the total number of pups observed the previous week from the total number observed in the current week. Only the maximum pup count from each sample day was used in these calculations.

From 4 July-1 August 1996, 2 July-13 August 1997, 1 July-14 August 1998, 30 June-18 August 1999, 22 June-1 August 2000, 29 May-11 July 2001, and 9 May-21 July 2002, we counted verified predation/feeding events during $1408 \mathrm{hr}$ of observation. A verified event was defined as one in which we saw a single non-egg prey or carrion item taken, carried, and/or eaten by one or more eagles. Numerous suspected predation events were not considered verified or counted because they did not meet at least one of the above criteria. We recorded date, time, number of subadult and adult eagles participating, and type of prey/food for each verified event.

From 10-28 July 2004, we spent 46 hr during 7 d tallying successful and unsuccessful predation attempts by subadult and adult eagles that swept down on gull chicks from the steep bluff to the west of Violet Point. Gull chicks captured in this manner were carried out of the colony before being eaten.

On 2 July 2004, toward the end of the gull incubation period but just prior to peak hatching, we inspected 332 gull nests along a 700-m × 2-m transect, and noted the habitat type and condition of each nest. Numbers of eggs and/or chicks in each nest were counted, as well as numbers of nests with eagle-fragmented eggshell. Cannibalistic Glaucouswinged Gulls and Northwestern Crows (Corvus caurinus) also take gull eggs on Protection Island. These predators, however, typically fly from nest sites with single eggs before devouring them elsewhere. Eagles, by contrast, generally devour entire clutches of eggs at the nest site and leave broken eggshells scattered close to or in the nest. No mammalian egg-predators, such as striped skunks (Mephitis mephitis) and raccoons (Procyon lotor), reside on Protection Island.

On 7 October 2001, all bones and other prey items within each $1-\mathrm{m}^{2}$ quadrat of a $4 \times 4$-m grid beneath the eagle nest located in the eastern wooded area (Fig. 1) were collected from surface litter and the top $3 \mathrm{~cm}$ of the soil. The minimum number of individuals for each species was determined using the most abundant skeletal unit for that species. Bones were identified by comparison with museum specimens.

All $\chi^{2}$ tests were carried out at the $5 \%$ significance level. Expected values were determined as indicated with the results of each test. Test results must be considered with caution because the same eagles participated in multiple events, an unavoidable violation of the assumption of independence.

\section{REsults}

Bald Eagle Movement Patterns and Landing Sites in Relation to Food Availability. Maximum numbers of Bald Eagles visible per day on Violet Point from 1993 to 2002 ranged from eight in 1994 to 26 in 1999 (Fig. 2). Subadults outnumbered adults during all years. The observed ratio of subadults to adults peaked at 4.33 in 1997 , declining to 1.88 in 2002. Eagles that foraged on Violet Point included members of the pair nesting on Protection Island 


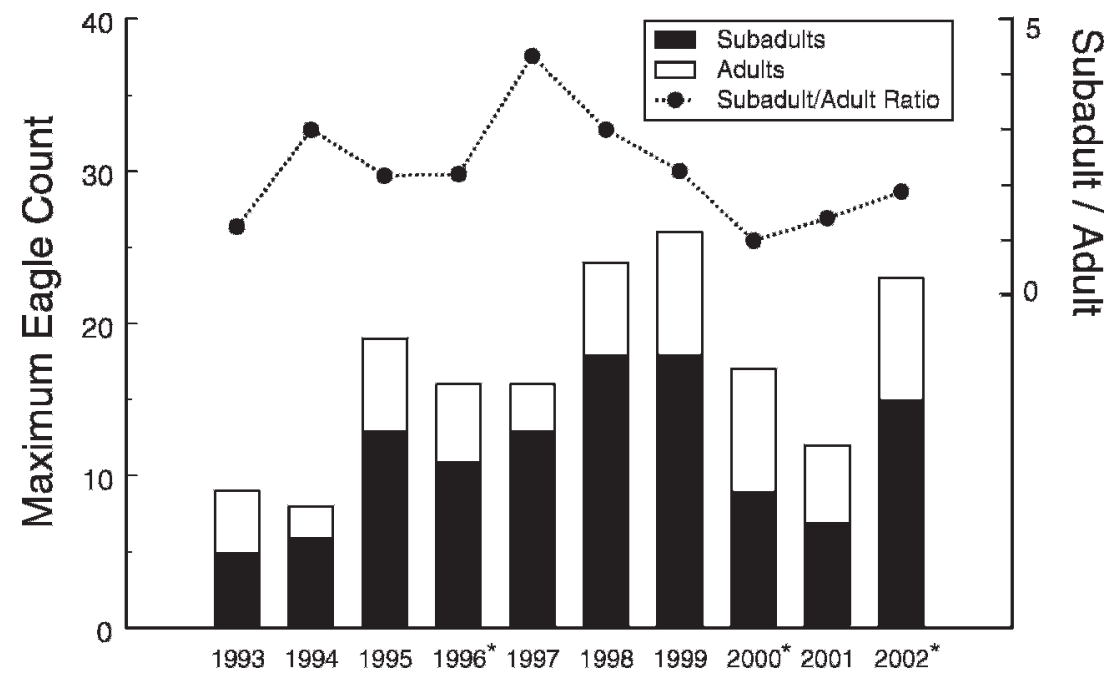

Figure 2. Annual maximum numbers of subadult and adult Bald Eagles observed on Protection Island from 1993 to 2002. Dotted line indicates changing ratio of subadults to adults. Systematic counts were not made on years indicated by an asterisk (*).

(as determined on the basis of observations of adults carrying prey from Violet Point to the nest), fledglings from this pair, and other unidentified juvenile and adult eagles.

During the six-week sampling periods (each comprising one 17-hr observation per week) in 1993-95, the number of Bald Eagle flights was consistently highest during the second week in July (Fig. 3a), coincident with a steep increase in the numbers of gull chicks hatching (Fig. 3b) and with the onset of increasing numbers of seal pup births on Protection Island (Fig. 3c).

Landing choices by adults and subadults on Violet Point in 1993-95 were not equal. Eagles were more likely to land in seal haul-out areas along the beach than in non-beach areas. Of 473 observed landings by eagles of known age class, seal haul-out areas along the beach were more commonly used (124 adults and 321 subadults) and the limited landings in gull-nesting, non-beach areas were dominated by subadults ( 2 adults and 26 subadults; hypothesis $1: \chi^{2}=5.79, \mathrm{df}=1, P=0.016$; expected values based on the proportion of landings by adults and subadults in each area).

In addition, the presence of Bald Eagles on the beach was more likely when harbor seals were hauled out on the beach. Of 492 top-of-the-hour counts on 33 observation days in 1995, 1997, 1998, 1999, and 2001, eagles were present during 247 counts when seals were present and during 46 counts when seals were not present; eagles were not present during 152 counts when seals were present and during 47 counts when seals were not present (hypothesis 2: $\chi^{2}=4.85$, df $=1, P=0.028$; expected values based on proportions of hourly counts with and without eagles and with and without seals present).

Bald Eagle Feeding Behavior. Most verified feeding events involved harbor seal afterbirths and pups and Glaucous-winged Gull chicks and adults (Table 1). Eagle predation patterns matched prey availability temporally. Gull-egg predation, which we could not quantify precisely, occurred primarily in June. Predation on adult gulls and gull chicks occurred from mid-May through mid-August with chicks taken primarily during the latter portion of this period (Fig. 3d). Most (85.3\%, $n=68$ ) feeding on harbor seal afterbirths and pups occurred in July (Fig. 3e). An overall decline in foraging events began in mid-July, which corresponded with a sharp decline in eagle activity on the island (Fig. 3a).

Of the observed predation/feeding events, $26.3 \%$ involved seal afterbirths, with 1 to 16 eagles involved and the highest average and highest subadult:adult ratio of eagle participants for any food item (Table 2). Aerial chases and pirating were common. Of 31 such feedings observed (based on cases in which eagle ages were known, here and for the three prey types below), 128 subadult and 30 adult eagles participated, a nonsignificant difference 

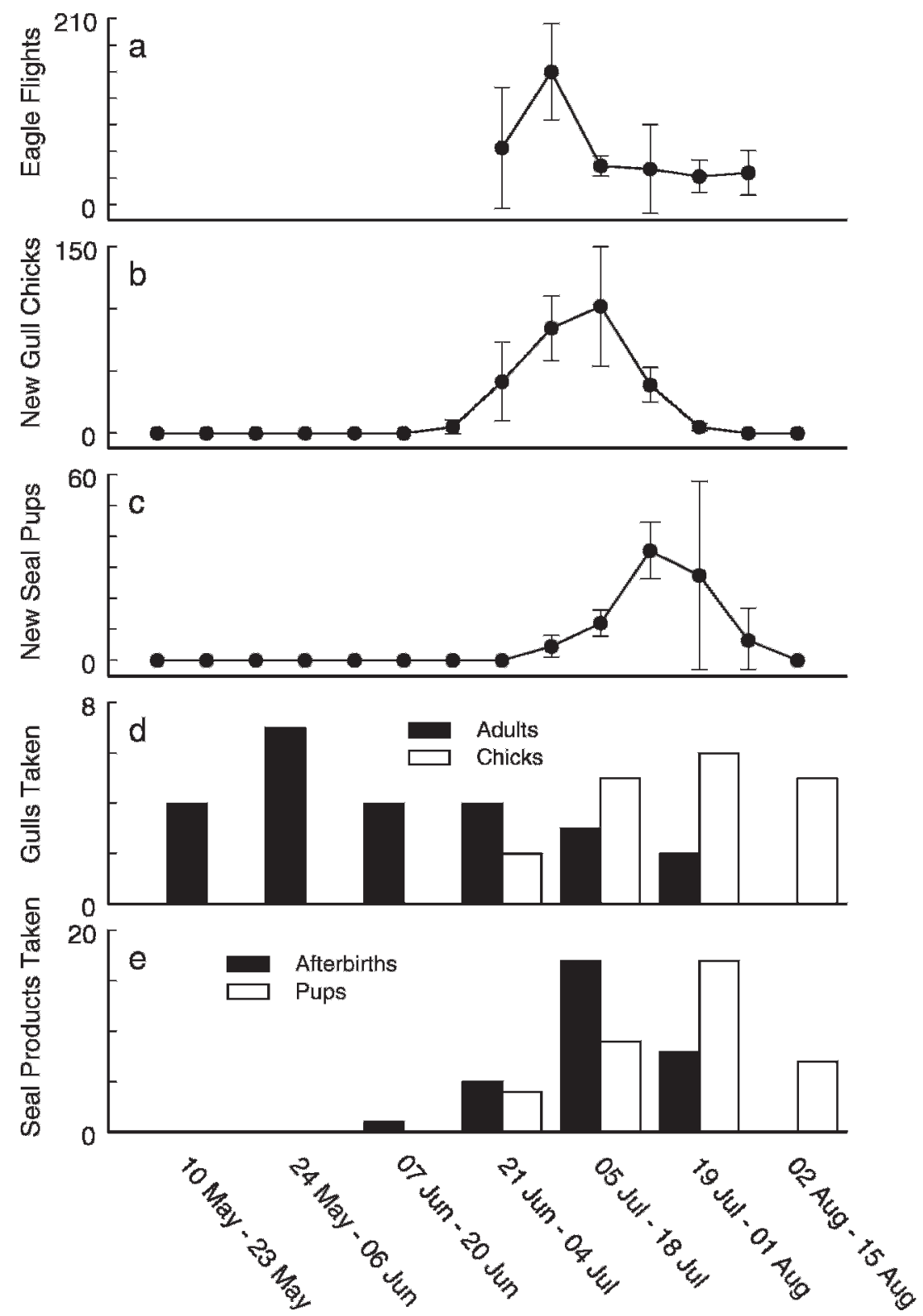

Figure 3. Bald Eagle flights and verified feeding events observed on Protection Island relative to prey availability and time. (a) Mean ( \pm SD) number of eagle flights counted per day on weekly sample days in 1993, 1994, and 1995; (b) Mean ( \pm SD) numbers of new gull chicks hatched in five experimental plots on Violet Point in 2006 and 2007; (c) Mean ( \pm SD) numbers of new seal pups estimated on Violet Point on weekly sample days in 1998 and 1999; (d) total numbers of feeding events involving adult gulls (black bars) and gull chicks (white bars) from 1996 to 2002; (e) total numbers of observed eagle feeding events involving seal afterbirths (black bars) and seal pups (white bars) from 1996 to 2002 . Graphs $\mathrm{a}-\mathrm{c}$ are based on weekly intervals, whereas histograms d-e are based on 2-wk intervals due to the relatively low number of observed and verified feeding events. Error bars do not appear in d and e because the counts represented were not made systematically as in a-c (see Methods). 
Table 1. Numbers of Bald Eagle food items seen taken/ eaten from 1996 to 2002 during May-August, and numbers of food items counted on 7 October 2001 within a $16-\mathrm{m}^{2}$ sample area beneath one Bald Eagle nest on Protection Island. Counts of items beneath the nest are based on minimum numbers of animals represented by skeletal elements.

\begin{tabular}{lcc}
\hline & \multicolumn{2}{c}{ NUMBER OF } \\
& \multicolumn{2}{c}{ FOOD ITEMS } \\
\cline { 2 - 3 } \multicolumn{1}{c}{ FoOD ITEM } & $\begin{array}{c}\text { SEEN } \\
\text { TAKEN }\end{array}$ & BENEATH \\
NEST \\
\hline Harbor seal (Phoca vitulina) pups & 37 & 0 \\
Harbor seal afterbirths & 31 & 0 \\
Glaucous-winged Gull (Larus & & \\
$\quad$ glaucescens) adults & 24 & 17 \\
Glaucous-winged Gull chicks & 18 & 0 \\
Pelagic Cormorants & & \\
$\quad$ (Phalacrocorax pelagicus) & 2 & 35 \\
Pigeon Guillemots (Cepphus columba) & 1 & 6 \\
Double-crested Cormorants & & \\
$\quad$ (Phalacrocorax auritus) & 1 & 4 \\
Rhinoceros Auklets & & \\
$\quad$ Cerorhinca monocerata) & 0 & 79 \\
Fish & 0 & 9 \\
Brant (Branta bernicla) & 0 & 1 \\
Other & 4 & 11 \\
\hline
\end{tabular}

from expected values $\left(\chi^{2}=1.79, \mathrm{df}=1, P=0.181\right.$; expected values here and for the three prey types below based on proportions of subadult [0.765] and adult [0.235] eagle flights $[n=971]$ monitored in 1993-95). We observed no feedings on afterbirths past July, although these items were still available.

Dead seal pups were eaten in $31.4 \%$ predation/ feeding events observed, with 1 to 13 eagles associated with each event and a notably lower ratio of subadult:adult eagle participants than for afterbirths (Table 2). In 35 feedings on seal pups, 106 subadult and 40 adult eagles were involved, which did not differ significantly from expected values $\left(\chi^{2}\right.$ $=1.23, \mathrm{df}=1, P=0.267)$.

Adult gulls accounted for $20.3 \%$ of the observed food items, with one to five eagles involved in each feeding event. In 16 such events, 22 subadult and 10 adult eagles were involved, which did not differ from expected values $\left(\chi^{2}=1.07\right.$, df $=1, P=$ $0.301)$. Gull chicks made up another $15.3 \%$ of the observed food items, with one to six eagles participating in each event. In 15 such events, significantly more adult $(n=10)$ than subadult $(n=13)$ eagles than expected were involved $\left(\chi^{2}=5.11\right.$, df $=1, P=$
Table 2. Average numbers of Bald Eagles feeding on various prey items on Protection Island. Ratios of subadult to adult Bald Eagles are indicated.

\begin{tabular}{lcccc}
\hline \multicolumn{4}{c}{ Average Number of Eagles Per Feeding Event } \\
\hline \multicolumn{1}{c}{ Food Item } & $\begin{array}{c}\text { Subadult } \\
+ \text { Adult }\end{array}$ & Subadult & Adult & $\begin{array}{c}\text { Subadult } \\
\text { Adult }\end{array}$ \\
\hline Seal afterbirth & 5.10 & 4.13 & 0.97 & 4.3 \\
Dead seal pup & 4.17 & 3.03 & 1.14 & 2.7 \\
Adult gull & 2.00 & 1.38 & 0.63 & 2.2 \\
Gull chick & 1.53 & 0.87 & 0.67 & 1.1 \\
\hline
\end{tabular}

0.024). When multiple eagles were involved, participants chased the captor and attempted to steal the prey. The ratio of subadult:adult eagles was considerably lower for gull prey than for feeding events involving seals, with the ratio for adult gull prey twice that for gull chicks (Table 2), a falsification of hypothesis 3 .

Eagles attempting to capture prey while in flight (stooping) snatched chicks from the gull colony surface and took them elsewhere to feed. Fifty-five percent $(n=20$ of 36$)$ of subadults and $60 \%(n=$ 15 of 25) of adults made successful captures during stoops (hypothesis 4: $\chi^{2}=0.049, \mathrm{df}=1, P=0.825$; expected values based on the proportions of subadult [0.59] and adult [0.41] attempts).

A significantly higher percentage of sample nests in tall grass habitat (73.2\%) contained eagle-fragmented eggshells than in sparse vegetation habitat (29.8\%; hypothesis $5: \chi^{2}=34.06, \mathrm{df}=1, P<0.001$; expected values based on proportions of nests in tall grass [0.21] and sparse vegetation [0.79] habitats; Fig. 4).

Prey Remains Beneath the Eagle Nest. Mostly disarticulated skeletal prey remains were scattered over a 12-m diameter area beneath the eagle nest. Of 1874 avian bones collected in the $16-\mathrm{m}^{2}$ sample area, 1687 were non-vertebrae, of which $93 \%$ were identified to species. Humeri, ulnae, and radii predominated. A minimum of 152 birds were represented (Table 1). Rhinoceros Auklets were most common, followed by Pelagic Cormorants, Glaucous-winged Gulls, Pigeon Guillemots, Double-crested Cormorants, and Brant (Branta bernicla), respectively; one Guinea Fowl (Numida meleagris) skull and bones of nine unidentified birds also were found. Fish bones $(n=119)$ included cranial elements and 14 vertebrae. Remains of scorpaeniformes, including a minimum of five rockfish (Sebastes sp.), one red Irish lord (Hemilepidotus hemilepidotus), one great 


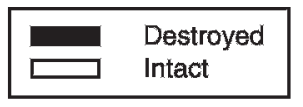

(56) (208)

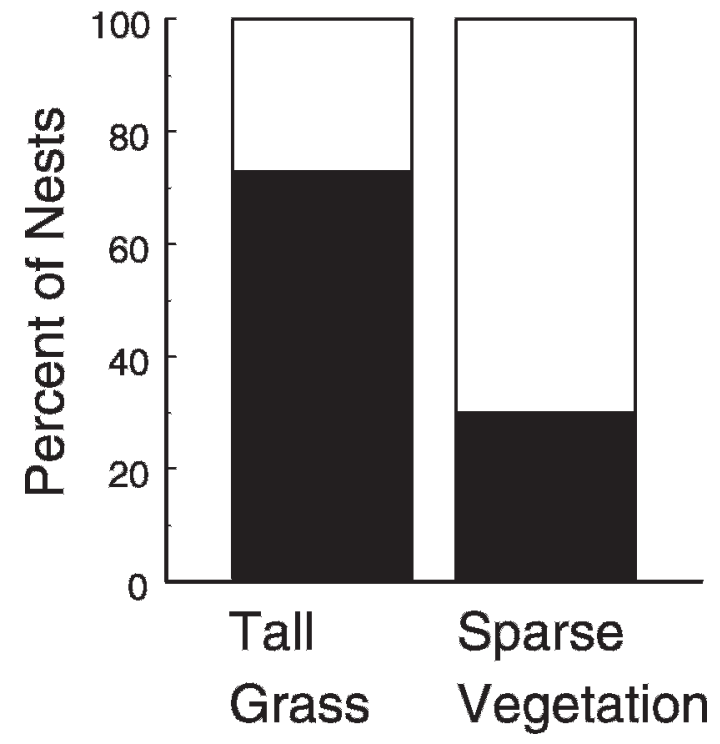

Figure 4. Percentage of transected Glaucous-winged Gull nests in tall grass and sparse vegetation habitats found intact and destroyed by eagles. Data collected on 2 July 2002 on Violet Point, Protection Island. Total numbers of nests per sample appear in parentheses above each bar.

sculpin (Myoxocephalus polyacanthocephalus), and one buffalo sculpin (Enophrys bison), predominated. The dentary and several other bones of a salmonid ( $\mathrm{On}$ corhynchus sp.) were included. One striped skunk skull and three butchered beef bone fragments were also present.

\section{DISCUSSION}

Eagle flights over the gull colony often resulted in dramatic cyclonic flight patterns ("eagle disturbances") by the gulls that were virtually impossible for humans to ignore. During research on Violet Point in the 1980s (e.g., Galusha and Carter 1987, C. Amlaner pers. comm.), few eagle disturbances were observed each day. In 1995, however, we counted 213 eagle flights within a single day, many of which created large disturbances (Galusha and Hayward 2002). This observed increase in eagle disturbances comports with observations at marine bird colonies in the Strait of Georgia, British Columbia (Sullivan et al. 2002) and at Tatoosh Island, Washington (Parrish et al. 2001).

Early in the gulls' breeding season, eagle disturbances were particularly dramatic. For example, on 16 May 2002 at 22:05 H, and again on 3 June 2002 at 08:45 H, approximately half the gulls on the Violet Point colony vacated in response to eagle predation on adult gulls. Only after the eagles completed feeding and vacated the colony did gull residents return to their territories. Both disturbances occurred prior to peak laying and incubation, so most gulls had little reason not to abandon their nest sites temporarily.

The frequency and intensity of Bald Eagle disturbances on Protection Island vividly reflected the predation pressure eagles exert on prey populations. Our observations focused primarily on events involving seals and gulls, but we commonly observed Pigeon Guillemots, Pelagic Cormorants, Doublecrested Cormorants, and other potential prey fleeing nesting and loafing areas in response to eagle flights. Even adult harbor seals shifted position at times in response to nearby eagle landings.

Eagles landed on the beach more frequently than in the gull colony and they were more likely to be located on the beach when seals were present than when they were not present. At mean lower low water (MLLW), the seal haul-out area was approximately half the size of the gull-nesting area; at higher tide levels there was even less exposed beach for haul-out, further accentuating the preference of eagles for landing in the seal haul-out area. Thus, the presence of harbor seals appears to be a major attractant for eagles. Eagles landed near seal pups temporarily or permanently abandoned by their mothers, standing by passively for minutes or hours appearing to wait for the pups to die. However, eagles generally avoided attacking pups, except on three occasions (Hayward 2009).

Seabirds commonly are represented in the nest litter and regurgitated pellets of Bald Eagles in the Pacific Northwest (e.g., Vermeer and Morgan 1989, Knight et al. 1990), although eagle diets inferred from direct observations contrast sharply with those inferred from prey remains at nests (Watson et al. 1991, Mersmann et al. 1992). Rhinoceros Auklets were most likely taken during early morning or late evening when these birds are active outside their nest burrows (Wilson and Manuwal 1986) and outside our observation periods. Other differences between the two data sources may be attributable to differences in prey brought to nestlings as com- 
pared with self-feeding of older eagles, to the fact that bones of some animals are more likely to preserve than others, to unique food preferences of the resident pair, and/or to interannual variation in prey availability, represented in the seven seasons of observed predation events but not reflected in the prey remains, which were collected in a single year.

Harbor seals constituted a major component of the diets of Bald Eagles on Protection Island in July, but the effect of eagles on seals is probably negligible given that most seal calories consumed are derived from afterbirths and dead pups (although see Hayward 2009). Our data suggest, however, that Bald Eagle feeding activity may substantially affect numbers of nesting Glaucous-winged Gulls and their breeding success (see also Sullivan et al. 2002, White et al. 2006). The effect on gulls is both direct, due to predation on gull eggs, juveniles, and adults, and indirect, due to eagle disturbances which provide opportunities for gulls and crows to steal the eggs of conspecifics (Thompson 1989, Hayward et al. 2000, Parrish et al. 2001). The $44 \%$ decrease in gull nests on Violet Point from 1993 to 2008 in part may be related to eagle activity. But the significance of this decline should be assessed in view of large increases in numbers of these birds over the last decades of the twentieth century. From 1960 to 1986, the nesting population of Glaucouswinged Gulls in the region doubled, an increase correlated with increased feeding activity at landfills (Verbeek 1986, Vermeer 1992, Sullivan et al. 2002). Glaucous-winged Gull populations may have been artificially inflated due to the availability of human food waste and the decline of Bald Eagles. Increased Bald Eagle predation, along with the covering of landfills, may have brought Glaucous-winged Gull numbers closer to historic levels.

Differences in subadult:adult ratios at feeding events appear to be due to a complex interaction of food size, caloric density, availability, and ease of acquisition. Assuming that $70.6 \%$ of mammal carcasses, $100 \%$ of afterbirths, and $68.5 \%$ of bird carcasses are edible (Stalmaster and Gessaman 1982), average edible masses of observed food items are as follows: harbor seal pup, $7.70 \mathrm{~kg}$ (Ellis et al. 2000); seal afterbirth, $1.34 \mathrm{~kg}$ (Anonymous 2004); adult Glaucous-winged Gull, 0.72 kg (Vermeer 1963); average-sized Glaucous-winged Gull chick, $0.36 \mathrm{~kg}$ (Vermeer 1963). A Bald Eagle can gorge on and store in its crop up to $0.924 \mathrm{~kg}$ of food per day (Stewart 1970). Based on these figures, in a single day a seal pup could fill the crops of 8.3 eagles and a seal afterbirth could fill the crops of 1.5 eagles; one eagle could devour 1.3 adult gulls or 2.6 average-size gull chicks. In view of these estimates, our observed average of 4.2 eagles feeding on each seal pup would involve little competition, which was consistent with our observations. By contrast, our observed average of 5.1 eagles feeding on one afterbirth would involve intense competition, also consistent with our observations. Curiously, intense competition for afterbirths occurred despite their relatively low caloric density $(4.73 \mathrm{~kJ} / \mathrm{g}$ for placentas of harp seal [Pagophilus groenlandicus; Lavigne and Stewart 1979], versus $13.8 \mathrm{~kJ} / \mathrm{g}$ for pup carcasses of southern elephant seals [Mirounga leonine; Favero 1996]; data unavailable for harbor seals). A rapid decline in observed consumption of afterbirths, coupled with an increase in observed consumption of pups during mid-July when both seal products remain abundant (Fig. 3c, 3e), suggest that eagles switch to a preference for pups later in the season. The edible caloric density of adult and juvenile gulls ranges from 4.19-8.37 kJ/kg (Dunn and Brisbin 1980), intermediate between that of afterbirths and pups.

The kill rate on adult gulls by eagles was impossible to determine because most adult gulls were attacked in tall grass, limiting our ability to see the outcomes of these events. Gulls nesting in tall grass were last to respond to human presence in the colony, bursting out of their grass tunnels just 1-3 m ahead of us. Because of their limited visibility, such gulls would be especially vulnerable to eagle attack. A higher proportion of eggs were taken in tall grass than in sparse vegetation, and predation on gull chicks was perpetrated disproportionately by adult eagles. The tall vegetation likely prevented diving gulls from striking the heads of foraging eagles; when eagles stood in sparsely vegetated areas of the colony they spent much of their time repeatedly ducking to avoid aerial attacks by gulls.

Eagles that swept down from perches on the bluff preyed on gull chicks in sparsely vegetated areas. During such stoops, hundreds of adult gulls swirled around the attacker, creating a distracting and threatening flight-space above the target. A flying predator would need to be completely focused and well-practiced to regularly snag the small, cryptically-colored gull chicks, which often run during disturbances. In fact, after stoops, eagles commonly fly up from target sites with only grass in their talons. Thus, it is not surprising that adult eagles were 
proportionately more likely to prey on gull chicks than were less experienced subadult eagles.

Further study of the effects of eagle disturbances on gull behavior and reproductive success on Protection Island is required to evaluate the ultimate consequences of eagle behaviors on gull populations.

\section{ACKNOWLEDGMENTS}

We thank Robert Edens, Jean Takekawa, and Kevin Ryan for permission to work on Protection Island National Wildlife Refuge. Field help was provided by Christina Burden, Clara Logan, Cheryl Moffett, Dennis Moffett, Mitch Northam, Karl Phillips, and Shanna Poirot. Barry Chernoff provided access to skeletal specimens for sample identification, and Phillip Willink, Kevin Swagel, and Rebecca Thomas helped classify fish remains at the Field Museum of Natural History, Chicago; David Willard provided access to skeletal specimens of birds there as well. Katherine Pearson and Theodore Pietsch opened the University of Washington Fish Collection to us and helped with specimen identification, as did Jay Orr. Washington Department of Fish and Wildlife provided data on the historical breeding success of Protection Island eagles. Julia Parrish, Craig Thompson, Ian Warkentin, Jim Watson, and an anonymous reviewer provided helpful critiques of earlier drafts of this manuscript. Walla Walla University's Rosario Beach Marine Laboratory furnished logistical support. This research was funded by faculty grants from Andrews University and Walla Walla University, and by National Science Foundation grants DMS-0314512 and DMS0613899 (JLH and SMH) and DMS-0614473 (JGG).

\section{Literature Cited}

AnOnymous. 2004. Seals and sea lions. http://medicine. ucsd.edu/cpa/seal.htm. (last accessed 29 March 2009.)

Anthony, R.G., J.A. Estes, M.A. RiccA, A.K. Miles, And E.D. Forsman. 2008. Bald eagles and sea otters in the Aleutian archipelago: indirect effects of trophic cascades. Ecology 89:2725-2735.

Cowles, D.L. AND J.L. Hayward. 2008. Historical changes in the physical and vegetational characteristics of Protection Island, Washington. Northwest Sci. 82: 174-184.

DunN, E.H. AND I.L. BRISBIN, JR. 1980. Age-specific changes in the major body components and caloric values of Herring Gull chicks. Condor 82:398-401.

Ellis, S.L., W.D. Bowen, D.J. Boness, and S.J. Iverson. 2000. Maternal effects on offspring mass and stage of development at birth in the harbor seal, Phoca vitulina. J. Mammal. 81:1143-1156.

FAVEro, M. 1996. Foraging ecology of pale-faced sheathbills in colonies of southern elephant seals at King George Island, Antarctica. J. Field Ornithol. 67:292-299.

Galusha, J.G. And R.L. Carter. 1987. Do adult gulls recognize their own young: an experimental test. Stud. Avian Biol. 10:75-79.
AND J.L. HAYWARD. 2002. Bald Eagle activity at a gull colony and seal rookery on Protection Island, Washington. Northwest. Nat. 83:23-25.

, B. Vorvick, M.R. OpP, AND P.T. VORVICK. 1987. Nesting season censuses of seabirds on Protection Island, Washington. Murrelet 68:103-107.

HAYWARD, J.L. 2003. Sexual aggression by a male northern elephant seal on harbor seal pups in Washington. Northwest. Nat. 84:148-150.

2009. Bald eagle predation on harbor seal pups. Northwest. Nat. 90:51-53.

, S.M. Henson, C.J. Logan, C.R. Parris, M.W. Meyer, AND B. Dennis. 2005. Predicting numbers of hauled-out seals: a mathematical model. J. Appl. Ecol. 42:108-117.

, D.K. Zelenitsky, D.L. Smith, D. ZaFt, And J.K. Clayburn. 2000. Eggshell taphonomy at modern gull colonies and a dinosaur clutch site. Palaios 15: 343-355.

Henson, S.M., B. Dennis, J.L. Hayward, J.M. Cushing, And J.G. Galusha. 2007. Predicting the dynamics of animal behaviour in field populations. Anim. Behav. 74: 103-110.

Knight, R.L., P.J. Randolph, G.T. Allen, L.S. Young, AND R.J. Wigen. 1990. Diets of nesting Bald Eagles (Haliaeetus leucocephalus) in western Washington. Can. FieldNat. 104:545-551.

Kroll, A.M. 1993. Haul out patterns and behavior of harbor seals, Phoca vitulina, during the breeding season at Protection Island, Washington. M.S. thesis, Univ. of Washington, Seattle, WA U.S.A.

LaVigne, D.M. ANd R.E.A. Stewart. 1979. Energy content of harp seal placentas. J. Mammal. 60:854-856.

Mersmann, T.J., D.A. Buehler, F.D. Fraser, and J.K.D. SeeGAR. 1992. Assessing bias in studies of Bald Eagle food habits. J. Wildl. Manage. 56:73-78.

PARRISH, J.K. 1995. Influence of group size and habitat type on reproductive success in Common Murres (Uria aalge). Auk 112:390-401.

- M. Marvier, AND R.T. PAINE. 2001. Direct and indirect effects: interactions between Bald Eagles and Common Murres. Ecol. Appl. 11:1858-1869.

Pearson, S.F., P.J. Hodum, M. Schrimp, J. Dolliver, T.P. Good, And J.K. Parrish. 2009. Rhinoceros Auklet (Cerorhinca monocerata) burrow counts, burrow density, occupancy rates, and associated habitat variables on Protection Island, Washington: 2008 research progress report. Washington Department of Fish and Wildlife, Wildlife Science Division, Olympia, WA U.S.A.

SPEICH, S.M. AND T.R. WAHL. 1989. Catalog of Washington seabird colonies. Biological Report 88, US Fish and Wildlife Service, Washington, DC U.S.A.

Stalmaster, M.V. 1987. The Bald Eagle. Universe Books, New York, NY U.S.A.

- AND J.A. Gessaman. 1982. Food consumption and energy requirements of captive Bald Eagles. J. Wildl. Manage. 46:646-654. 
STEWART, P.A. 1970. Weight changes and feeding behavior of a captive-reared Bald Eagle. Bird-Banding 41:103110 .

Sullivan, T.M., S.L. HazlitT, And M.J.F. Lemon. 2002. Population trends of nesting Glaucous-winged Gulls, Larus glaucescens, in the southern Strait of Georgia, British Columbia. Can. Field-Nat. 116:603-606.

Thompson, S.P. 1989. Observations of Bald Eagles eating Glaucous-winged Gull eggs in western Washington. Northwest. Nat. 70:13-14.

VENNESLAND, R.G. AND R.W. ButLer. 2004. Factors influencing Great Blue Heron nesting productivity on the $\mathrm{Pa}-$ cific coast of Canada from 1989 to 1999. Waterbirds 27:289-296.

VerbeEK, N.A.M. 1986. Aspects of the breeding biology of an expanded population of Glaucous-winged Gulls in British Columbia. J. Field Ornith. 57:22-33.

VermeER, K. 1963. The breeding biology of the Glaucous-winged Gull (Larus glaucescens) on Mandarte Island, B.C. Occasional Paper 13, British Columbia Provincial Museum, Victoria, British Columbia, Canada.
1992. Population growth of the Glaucous-winged Gull Larus glaucescens in the Strait of Georgia, British Columbia, Canada. Ardea 80:181-185.

AND K.H. Morgan. 1989. Nesting population, nest sites, and prey remains of Bald Eagles in Barkley Sound, British Columbia. Northwest. Nat. 70:21-26.

Watson, J.W., M.G. Garrett, and R.G. Anthony. 1991. Foraging ecology of Bald Eagles in the Columbia River estuary. J. Wildl. Manage. 55:492-499.

, D. Stinson, K.R. McAllister, And T.E. Owens. 2002. Population status of Bald Eagles breeding in Washington at the end of the 20th century. J. Raptor Res. 36:161-169.

White, A.F., J.P. Heath, And B. Gisborne. 2006. Seasonal timing of Bald Eagle attendance and influence on activity budgets of Glaucous-winged Gulls in Barkley Sound, British Columbia. Waterbirds 29:497-500.

WiLson, U.W. AND D.A. ManuWaL. 1986. Breeding biology of the Rhinoceros Auklet in Washington. Condor 88:143155 .

Received 27 November 2008; accepted 20 October 2009 Associate Editor: Ian G. Warkentin 